\title{
Data report: dolomite in Neogene sediments of the Belgica carbonate mound province, Porcupine Seabight, North Atlantic ${ }^{1}$
}

Jay M. Gregg ${ }^{2}$ and Tracy D. Frank ${ }^{3}$

\section{Chapter contents}

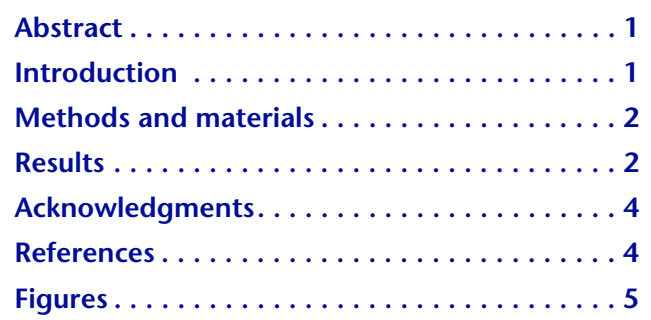

1Gregg, J.M., and Frank, T.D., 2009. Data report: dolomite in Neogene sediments of the Belgica carbonate mound province, Porcupine Seabight, North Atlantic. In Ferdelman, T.G., Kano, A., Williams, T., Henriet, J.-P., and the Expedition 307 Scientists, Proc. IODP, 307: Washington, DC (Integrated Ocean Drilling Program Management International, Inc.).

doi:10.2204/iodp.proc.307.207.2009

${ }^{2}$ Boone Pickens School of Geology, Oklahoma State University, Stillwater OK 74078, USA. Jay.gregg@okstate.edu

${ }^{3}$ Department of Geosciences, University of Nebraska-Lincoln, Lincoln NE 68588, USA.

\begin{abstract}
Dolomite was observed, using petrography, X-ray diffraction (XRD), and scanning electron microscopy (SEM), in cored Neogene sediments from the Porcupine Seabight in the north Atlantic Ocean, Integrated Ocean Drilling Program Expedition 307 Sites $\mathrm{U} 1316, \mathrm{U} 1317$, and U1318, $100 \mathrm{~km}$ off the west coast of Ireland. Trace amounts $(<10 \%$ of total carbonate component) of dolomite were observed in Challenger Mound, a deep coldwater mixed silicaclastic-carbonate mud mound located in the Porcupine Seabight. Significant dolomitization ( $>50 \%$ of total carbonate component) was observed primarily in Miocene strata in submound and off-mound sediments.

Petrographic examination of smear slides indicates that dolomite is composed of micrometer- to decimicron-sized, limpid, rhombic crystals. XRD analysis indicates that the dolomite is calcium rich and poorly ordered. SEM confirms light petrographic analysis of size and morphology of dolomite crystals, and electron microprobe analysis indicates that the dolomite is ferroan and displays distinct compositional zoning. Microbes and associated microbial filamentous structures were observed associated with dolomite crystals.

Saturation indexes of carbonate minerals calculated for interstitial waters collected from the three sites are consistent with the petrographic and XRD observation of dolomite.
\end{abstract}

\section{Introduction}

Challenger Mound (Belgica carbonate mound province) is located $\sim 100 \mathrm{~km}$ off the southwest coast of County Kerry, Ireland, in water depths between 550 and 1025 m (Figs. F1, F2). Miocene sediments in the region are composed of mixed siliciclastics (silts and clays) and carbonates (nannoplankton and coldwater metazoan skeletal debris). These sediments are overlain by Pliocene to Pleistocene coldwater coral carbonate mud mounds and their laterally equivalent sediments. The mounds are analogous in their largescale geometry and position on the shelf margin to fossil carbonate mud mounds common in Paleozoic strata (Lees and Miller, 1995). However, the Neogene mounds are dissimilar to Paleozoic carbonate mounds in that they are composed of coldwater coral in a matrix of mixed siliciclastic and carbonate sediments. They also lack stromatactis structures or any evidence of submarine car- 
bonate cementation as is common in Paleozoic carbonate mounds (De Mol et al., 2002; Henriet et al., 2005; Gregg et al., 2006).

The primary purpose of Integrated Ocean Drilling Program (IODP) Expedition 307 was to investigate the origin and evolution of the deep, coldwater carbonate mounds. Coring was conducted on and adjacent to Challenger Mound (Fig. F2). The "Expedition 307 summary" chapter and Kano et al. (2007) discuss the stratigraphy and sedimentary facies of the cored sediments. This data report documents the observation of trace diagenetic dolomite within the mud mound sediments and trace to significant dolomite in submound and off-mound sediments. This report also characterizes the dolomite petrographically as well as compositionally and documents the association of microorganisms with some occurrences of significant authigenic dolomite.

\section{Methods and materials}

Sediment cores were collected from 11 holes drilled at three sites within and adjacent to Challenger Mound during Expedition 307 in April and May 2005 (Fig. F2). A total of 361 smear slides of sediments were prepared and examined during coring on board the JOIDES Resolution and during the core description party in Bremen, Germany, in October 2005. Further analysis of smear slides was carried out at Oklahoma State University (USA). Five petrographic thin sections also were prepared from partly indurated sediment samples and analyzed.

A total of 209 powder X-ray diffraction (XRD) analyses were made on board the JOIDES Resolution during coring using a computer automated Phillips X-ray diffractometer. Scans were made from $2^{\circ}$ to $70^{\circ} 2 \theta$ with $0.02^{\circ}$ steps at $0.5 \mathrm{~s} / \mathrm{step}$. A total of 195 additional XRD analyses were made on core samples at Oklahoma State University using a computer automated Phillips PW 1830 X-ray diffractometer. Scans were made from $15^{\circ}$ to $55^{\circ} 2 \theta$ with $0.025^{\circ}$ steps at 0.5 s/step.

Scanning electron microscope (SEM) analysis was performed at Oklahoma State University using a JEOL JXA-35 SEM equipped with backscattered electron image and energy dispersive spectrometry capabilities and a JEOL 733 electron microprobe equipped with four crystal spectrometers and backscattered electron image and energy dispersive spectrometry capabilities. Both fractured samples and polished thin sections were carbon coated and examined using backscattered and secondary electron imagery. Compositional chemistry was analyzed with energy dispersive and wavelength dispersive spectrometry.

Shipboard interstitial water samples were obtained from 5-20 cm long whole-round intervals that were cut on the catwalk immediately after cores were recovered, capped, and taken to the laboratory. Sediments were placed in a titanium squeezer, and pore water was collected and analyzed using standard IODP protocol (for details see the "Methods" chapter).

\section{Results}

\section{Petrographic and X-ray diffraction analyses}

Carbonate composition of the mound sediments was characterized using X-ray diffraction (Fig. F3) and transmitted light microscopy (Fig. F4) (see XRD_DATA in "Supplementary material"). Smear slide descriptions (made by J.M. Gregg and other observers on board the JOIDES Resolution during Expedition 307) are available in "Core descriptions." Smear slides descriptions made by Gregg from Hole U1317E are available as .RTF files (see SMEARSLD in "Supplementary material"). XRD analyses are available as tab delineated .TXT files (see XRD_DATA in "Supplementary material").

Carbonate components of the mound sediments include low-Mg calcite nannoplankton (primarily coccoliths), aragonite skeletal (primarily coldwater coral) debris, and minor high-Mg calcite skeletal debris (foraminifers). Dolomite is petrographically characterized by micrometer- to decimicron-sized limpid, rhombic crystals (Fig. F4A, F4B, F4D). Noncarbonate components of the mound sediments mainly include continent-derived detrital quartz and feldspar, clay minerals, and biogenic sponge spicules. Mound sediments typically contain $>50 \%$ bulk carbonate; however, occasional meter-scale intervals were observed to be dominantly siliciclastic. Off-mound and submound sediments are similar in composition to mound sediments but are more dominantly composed of detrital siliciclastics, although frequent meter-scale intervals are dominantly carbonate in composition.

The ratio of dolomite to calcite in the carbonate component of the sediments was estimated by comparing the dolomite and calcite 104 line intensities. Aragonite content of most of the samples that were $\mathrm{X}$-rayed is minor and is not considered in this estimate. Low-Mg calcite (coccoliths) is the dominant carbonate phase observed in most samples analyzed. Dolomite commonly is present in cored sediments 
from trace amounts $(<10 \%$ of the carbonate based on XRD 104 line intensities) to $>50 \%$ of the total carbonate component (Fig. F5).

Dolomite and calcite stoichiometry (percentage magnesium composition) was calculated using the shift of their respective 104 lines from ideal stoichiometric composition (Lumsden and Chimahusky, 1980). Trace dolomite observed in the uppermost part of the Pliocene-Pleistocene strata displays near ideal stoichiometry, typical of Paleozoic dolomites, indicating a likely detrital origin and possible derivation from Paleozoic sediments in nearby Ireland. Lower in the section dolomite is calcium rich, which is typical of most Neogene dolomites (Budd, 1997). Corrections were not made for potential $\mathrm{FeCO}_{3}$ content in calcite or dolomite, so it must be assumed that part of the 104 line shift is due to Fe composition.

The 015 dolomite ordering line (Goldsmith and Graf, 1958) is present but slightly attenuated in all cases where dolomite was abundant enough in the sample for its observation. This attenuation indicates that the samples are mineralogically dolomite (not high-Mg calcite or "protodolomite") but display cation disorder. Cation disordering is also typical of Neogene dolomites (e.g., Gregg et al., 1992; Budd, 1997).

\section{Distribution of dolomite}

X-ray diffraction analysis of $>400$ samples from cores taken at Expedition 307 sites indicates that significant dolomitization (in some places $>50 \%$ of the total carbonate component of the sediment) has occurred or is occurring throughout the Miocene section with lesser amounts of dolomite within the Pliocene-Pleistocene sections in the off-mound areas (Fig. F5). Probable trace detrital dolomite was observed in the upper part of the mound. Trace authigenic dolomite was observed in the lower portion of the mud mound facies. Observation of dolomite in several lithified intervals of the Miocene section lead to the initial hypothesis that dolomitization was a factor in diagenetic lithification in these sediments. However, observation of lithified sections containing only trace and minor amounts of dolomite indicate that the two diagenetic processes likely are not related. Indeed, sections where dolomite exceeds 50\% of the total carbonate minerals present typically are unlithified.

The distribution of partially dolomitized intervals shown on Figure F5 is likely biased by the random nature of sampling for petrographic and X-ray analysis during the initial core descriptions. It is very probable that a systematic sampling of the cores would result in identification of more dolomitized intervals.

\section{SEM and electron probe analyses}

SEM and electron probe analysis of selected dolomitized samples from Sites U1317 and U1318 confirm that dolomite crystals are well-formed rhombs that appear to be replacing adjacent calcite, which appears to be undergoing dissolution (Fig. F6A, F6B, F6C). Backscattered electron imagery of sectioned dolomite crystals display distinct compositional zoning with respect to iron (Fig. F6D). Based on wavelength dispersive spectrometer analysis, it is estimated that dolomite composition ranges between $<1$ to $>5 \mathrm{~mol} \% \mathrm{FeCO}_{3}$. Dolomite does not display cathodoluminescence $(\mathrm{CL})$ under an electron beam, which is typically the case of ferroan dolomite, as iron quenches the CL response (Machel, 1985).

Of considerable interest is the observation of bacteria and associated filamentous organisms in several unconsolidated, partly dolomitized sediment samples (Fig. F7). These filaments have the characteristics of nannowires, which are electrically conductive structures that recently have been described in terrestrial sediments and have been cultured in the laboratory (Ntarlagiannis et al., 2006; E. Atekwana and Y. Gorby, pers. comm., 2007; Gramling, 2006). Possible relationships of these structures to dolomitization or other diagenetic processes ongoing in these sediments are a mater of speculation.

\section{Geochemical analysis of interstitial waters}

Figure F8 displays pore water saturation indexes for calcite, aragonite, and dolomite in core from Holes U1317A and U1317D through Challenger Mound and into the underlying Miocene sediments. According to these data, dolomite is the most stable of the three carbonate minerals in the Neogene section. Pore waters in the mud mound facies range from undersaturated to supersaturated with respect to dolomite. All pore waters analyzed in the submound section are supersaturated with respect to dolomite (Fig. F8). Dolomitization is especially predicted to occur above 25 meters below seafloor (mbsf) (Hole U1317A) and below 125 mbsf (Hole U1317B). These downcore geochemical trends are consistent with the observed occurrences of dolomite (Fig. F5) at Site U1317.

Similarly, incomplete analysis of water data predicts the distribution of dolomite as follows: at Site U1316 below 50 mbsf and at Site U1318 below 150 mbsf. These predicted distributions of dolomite match well 
with petrographic observations and XRD results throughout the study area (Fig. F8).

\section{Acknowledgments}

This research used samples and/or data provided by the Integrated Ocean Drilling Program (IODP). Funds for isotopic analyses were provided by a grant to the author from JOI-USSAC, administered by the U.S. Science Support Program administered by the Joint Oceanographic Institutes (now Ocean Leadership). Grant Heard ran the XRD analyses at Oklahoma State University, and Mark Russell performed laboratory analysis of interstitial pore waters. Patrick Meister provided a very helpful review of this paper. I am grateful to the Expedition 307 shipboard participants for discussions and assistance with sample collection.

\section{References}

Budd, D.A., 1997. Cenozoic dolomites of carbonate islands: their attributes and origin. Earth-Sci. Rev., 42(12):1-47. doi:10.1016/S0012-8252(96)00051-7

De Mol, B., Van Rensbergen, P., Pillen, S., Van Herreweghe, K., Van Rooij, D., McDonnell, A., Huvenne, V., Ivanov, M., Swennen, R., and Henriet, J.-P., 2002. Large deepwater coral banks in the Porcupine Basin, southwest of Ireland. Mar. Geol., 188(1-2):193-231. doi:10.1016/ S0025-3227(02)00281-5

Goldsmith, J.R., and Graf, D.L., 1958. Structural and compositional variations in some natural dolomites. J. Geol., 66:678-693.

Gramling, C., 2006. Looking for geophysical signs of life. Geotimes, 51(11). http://www.geotimes.org/nov06/ trends.html

Gregg, J.M., Howard, S.A., and Mazzullo, S.J., 1992. Early diagenetic recrystallization of Holocene ( $<3000$ years old) peritidal dolomites, Ambergris cay, Belize. Sedimentology, 39(1):143-160. doi:10.1111/j.1365-

3091.1992.tb01027.x
Gregg, J.M., Somerville, I.D., Foubert, A., and Doyle, E., 2006. Neogene deepwater carbonate mud-mounds and their Paleozoic counterparts—comparisons of geometry, sedimentology, and petrology. AAPG 2006 Annu. Conv.: Abstr. Vol., 15:40.

Henriet, J.-P., Kano, A., Malone, M.J., and the Expedition 307 Project Team, 2005. Modern carbonate mounds: porcupine drilling. IODP Sci. Prosp., 307. doi:10.2204/ iodp.sp.307.2005

Kano, A., Ferdelman, T.G., Williams, T., Henriet, J.-P., Ishikawa, T., Kawagoe, N., Takashima, C., Kakizaki, Y., Abe, K., Sakai, S., Browning, E.L., Li, X., and the Integrated Ocean Drilling Program Expedition 307 Scientists, 2007. Age constraints on the origin and growth history of a deep-water coral mound in the northeast Atlantic drilled during Integrated Ocean Drilling Program Expedition 307. Geology, 35(11):1051-1054. doi:10.1130/G23917A.1

Lees, A., and Miller, J., 1995. Waulsortian banks. In Monty, C.L.V., Bosence, D.W.J., Bridges, P.H., and Pratt, B.R. (Eds.), Carbonate Mud-Mounds: Their Origin and Evolution. Spec. Publ. Int. Assoc. Sedimentol., 23:191-271.

Lumsden, D.N., and Chimahusky, J.S., 1980. Relationship between dolomite nonstoichiometry and carbonate facies parameters. In Zenger, D.H., Dunham, J.B., and Ethington, R.L. (Eds.), Concepts and Models of Dolomitization. Spec. Publ.-Soc. Econ. Paleontol. Mineral., 28:123-137.

Machel, H.G., 1985. Cathodoluminescence in calcite and dolomite and its chemical interpretation. Geosci. Can., 12:139-147.

Ntarlagiannis, D., Atekwana, E., Hill, E., and Gorby, Y., 2006. Bacterial nanowires facilitate electron transfer in saturated porous media. Eos, Trans. Am. Geophys. Union, 87(52)(Suppl.):NS21A-05. (Abstract) http:// www.agu.org/meetings/fm06/waisfm06.html

Initial receipt: 21 July 2008

Acceptance: 14 April 2009

Publication: 3 July 2009

MS 307-207 
Figure F1. Location maps. A. The Belgica carbonate mound province located on the northeast edge of the Porcupine Seabight. B. Core locations (adapted from iodp.tamu.edu/scienceops/expeditions/exp307.html).

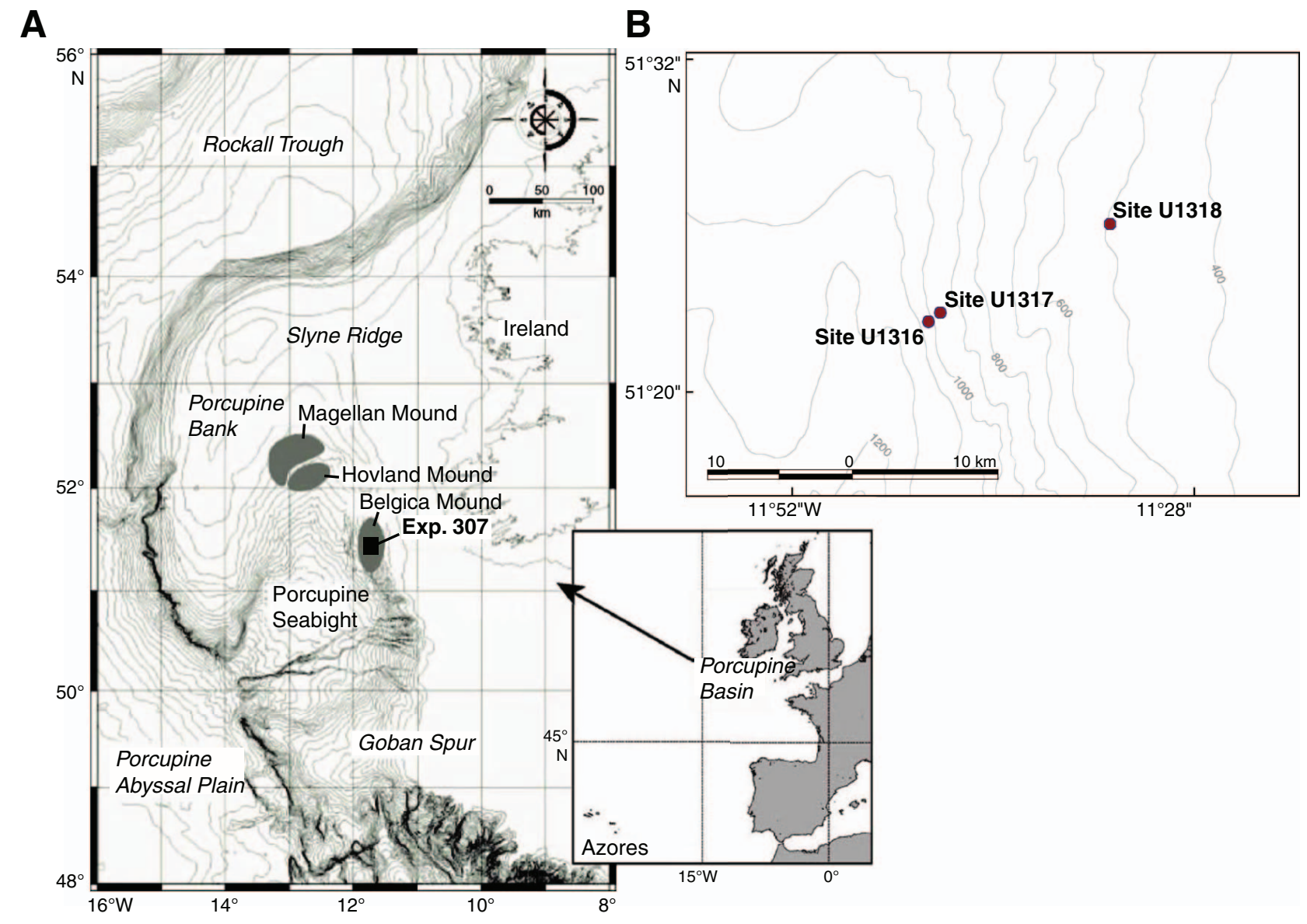


Figure F2. East-west stratigraphic profile through the Belgica mound province, showing the coring sites in and adjacent to Challenger Mound. Note that although sediments below and adjacent to the mound are described as "sand," "silt," and "clay," in many intervals carbonate content is $>50 \%$ (adapted from iodp.tamu.edu/scienceops/expeditions/exp307.html). $\mathrm{MBIO}=$ microbiology.

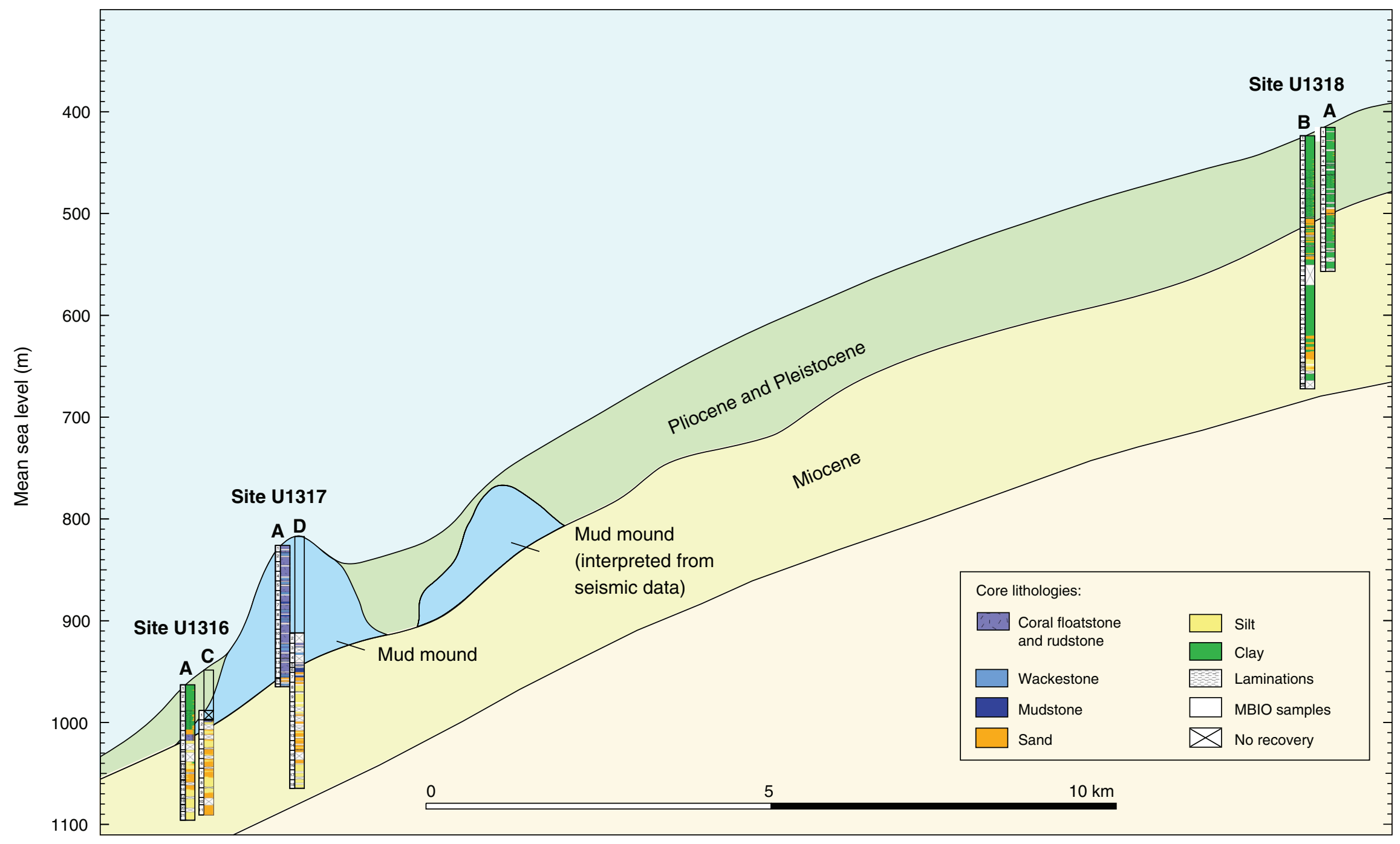


Figure F3. X-ray diffraction patterns of selected samples from Site U1317 and U1318 cores. (A), (B), and (D) are from unconsolidated samples and $(\mathrm{C})$ is from a lithified section of the core. All samples are from the Miocene (submound) part of the section. Note that carbonate is dominant over detrital quartz in all cases but C. Sediments in the Porcupine Basin cores range from dominantly siliciclastic to dominantly carbonate on a meter scale. $\mathrm{Qtz}=$ quartz, Cal = calcite, $\mathrm{Dol}=$ dolomite.
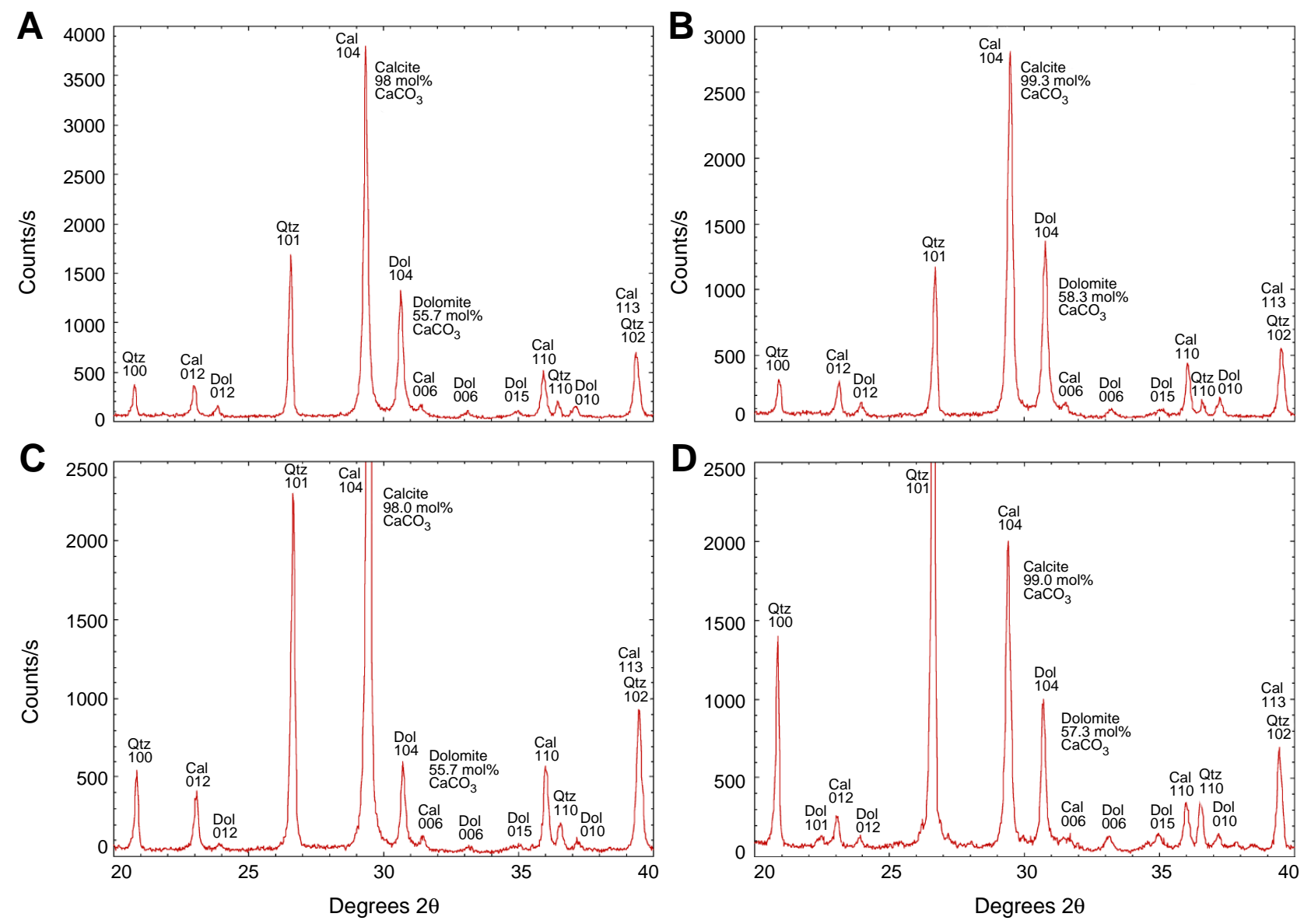
Figure F4. Photomicrographs of Porcupine Basin sediments. A. Smear slide of Core 307-U1317A-1H. Mud mound matrix is composed largely of coccoliths with a framework of coldwater coral. Note angular quartz silt grains and a dolomite rhomb in the lower left. B. Dolomite in a lithified interval in the Miocene near the bottom of Core 307-U1318B-24H. Note the dominance of dolomite rhombs in this field of view. Also present are silt-sized quartz, micritic calcite (coccoliths), and glauconite. Bulk X-ray diffraction analysis of this sample indicates that it actually contains only $\sim 20 \%$ dolomite. C. Thin section from a lithified zone in Core 307-U1316C$11 \mathrm{H}$. Groundmass is primarily nannoplankton and clay minerals. Note the abundance of silt-sized detrital quartz and glauconite. D. Close-up of $\mathrm{C}$ with dolomite rhombs visible. This sample contains $>30 \%$ dolomite based on X-ray analysis.
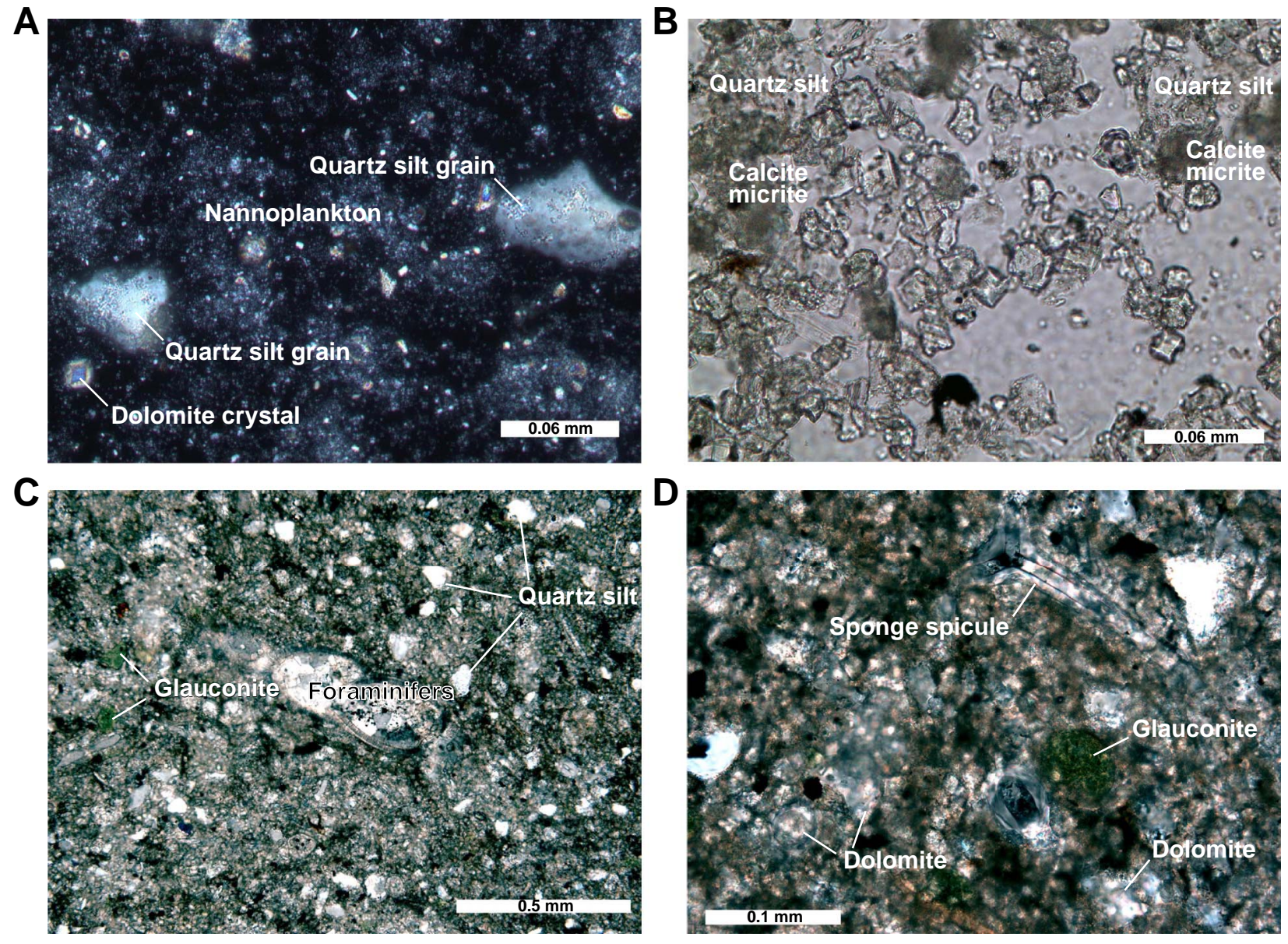
Figure F5. Schematic section showing relationships between sedimentary facies and stratigraphy and dolomitization in Expedition 307 core locations. $\mathrm{MBIO}=$ microbiology.

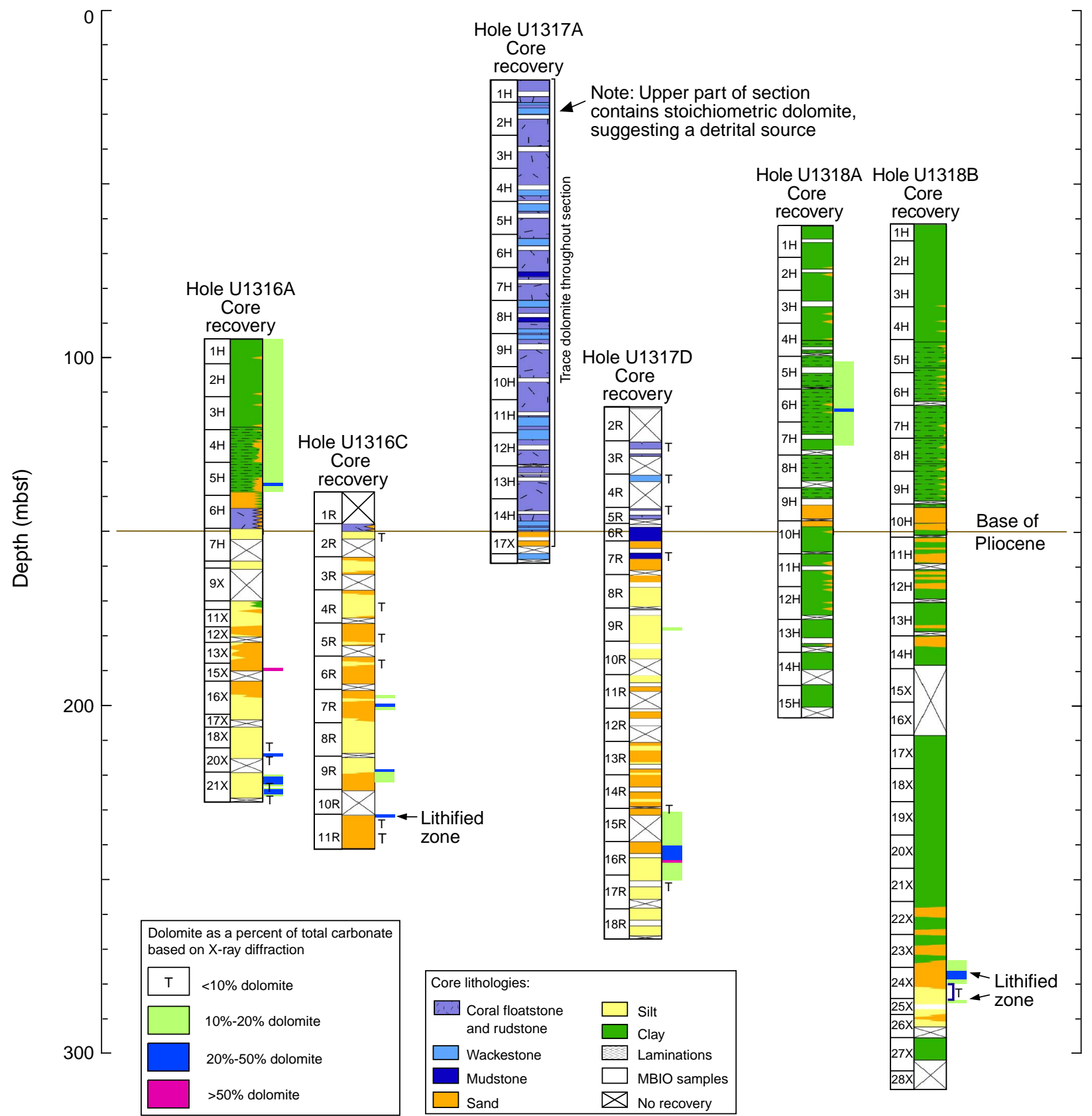


Figure F6. Electron micrographs of dolomite. A. Unconsolidated sediments (Core 307-U1317D-16H). Field of view shows relationship of dolomite rhombs with adjacent sediments; note abundance of clay mineral material. Upper right inset = electron dispersive spectrometer (EDS) "dot map" for $\mathrm{Mg}$, confirming the location of dolomite crystals. B. Same as A, close-up of dolomite rhomb. Note growth features on surface of dolomite crystal and lack of identifiable structures of nannoplankton in micrite matrix suggestive of dissolution. C. Dolomite in a lithified sample (Core 307-U1318B-24H). Dolomite rhombs and associated sediment. D. Backscattered electron image of a sectioned dolomite crystal in a lithified interval of sediment. Note distinctive compositional zoning. Upper right inset $=$ wavelength dispersive dot map of iron distribution.
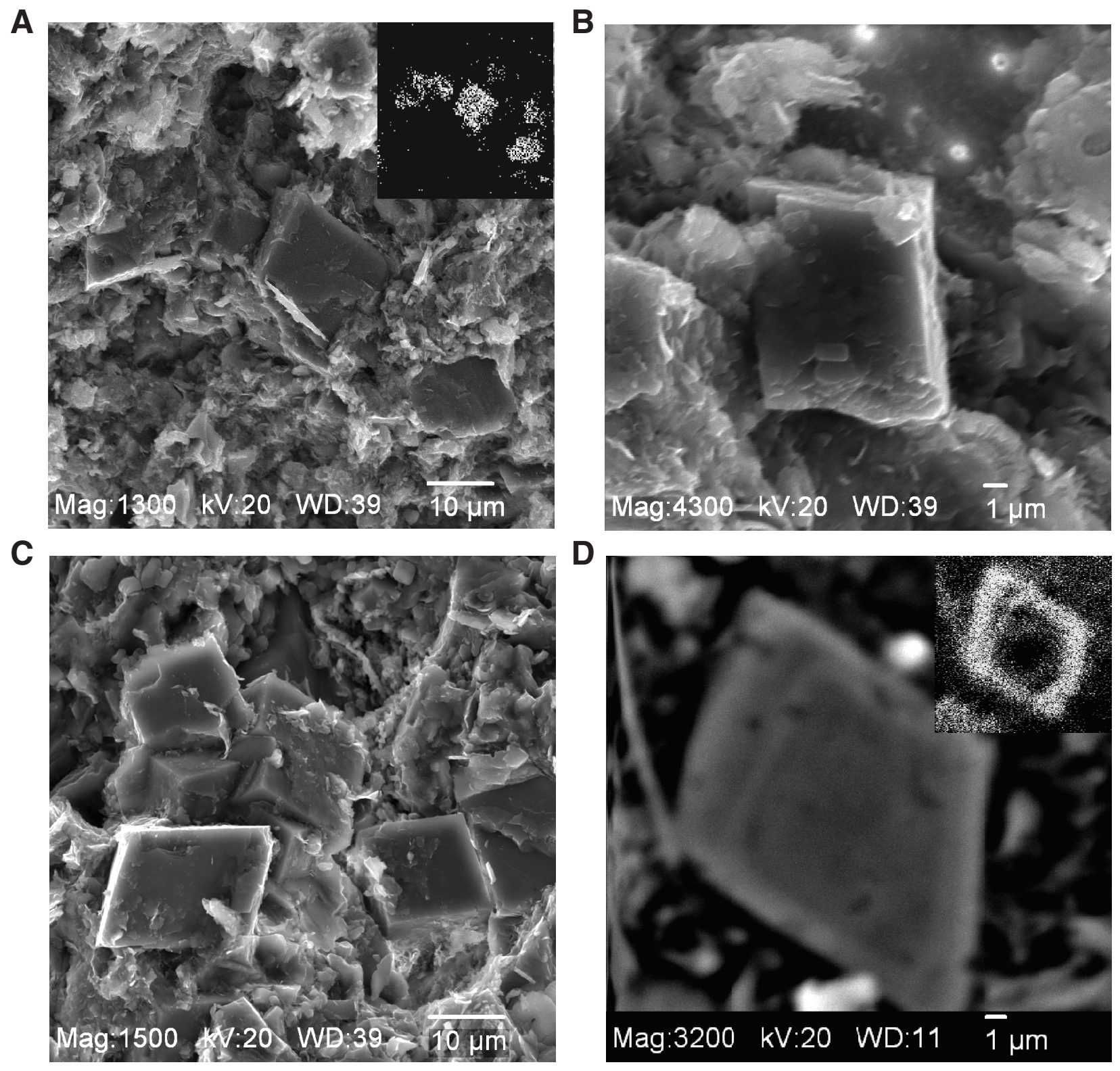
Figure F7. Electron micrographs of dolomite. A. Dolomite in an unlithified sample associated with microbial structures and filaments (Core 307-U1318B-24H). B. Close-up of upper right dolomite crystal in A with attached microbial filaments.

A

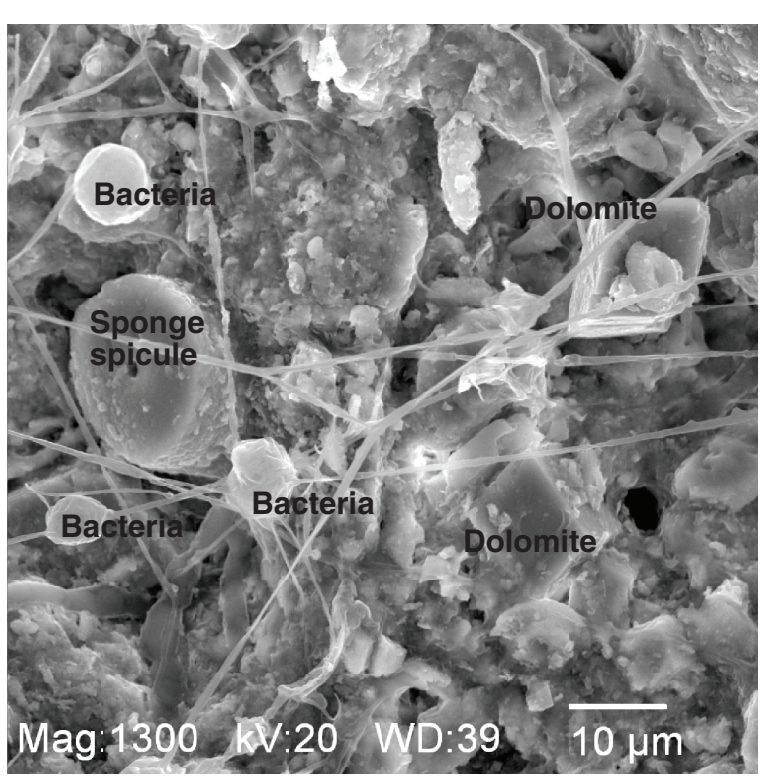

B

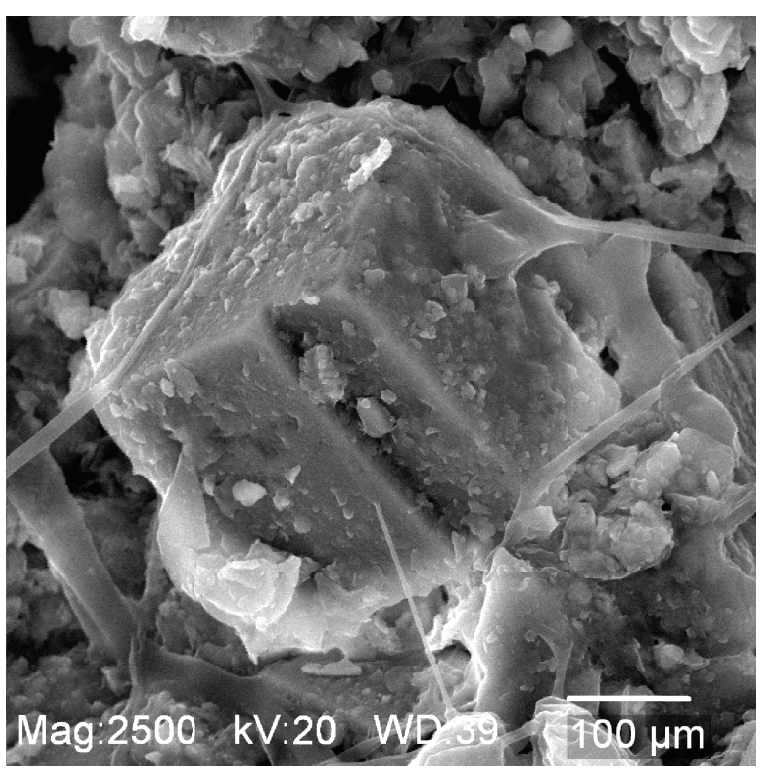


Figure F8. Saturation index for interstitial waters collected from Site U1317 cores for calcite, aragonite, and dolomite.

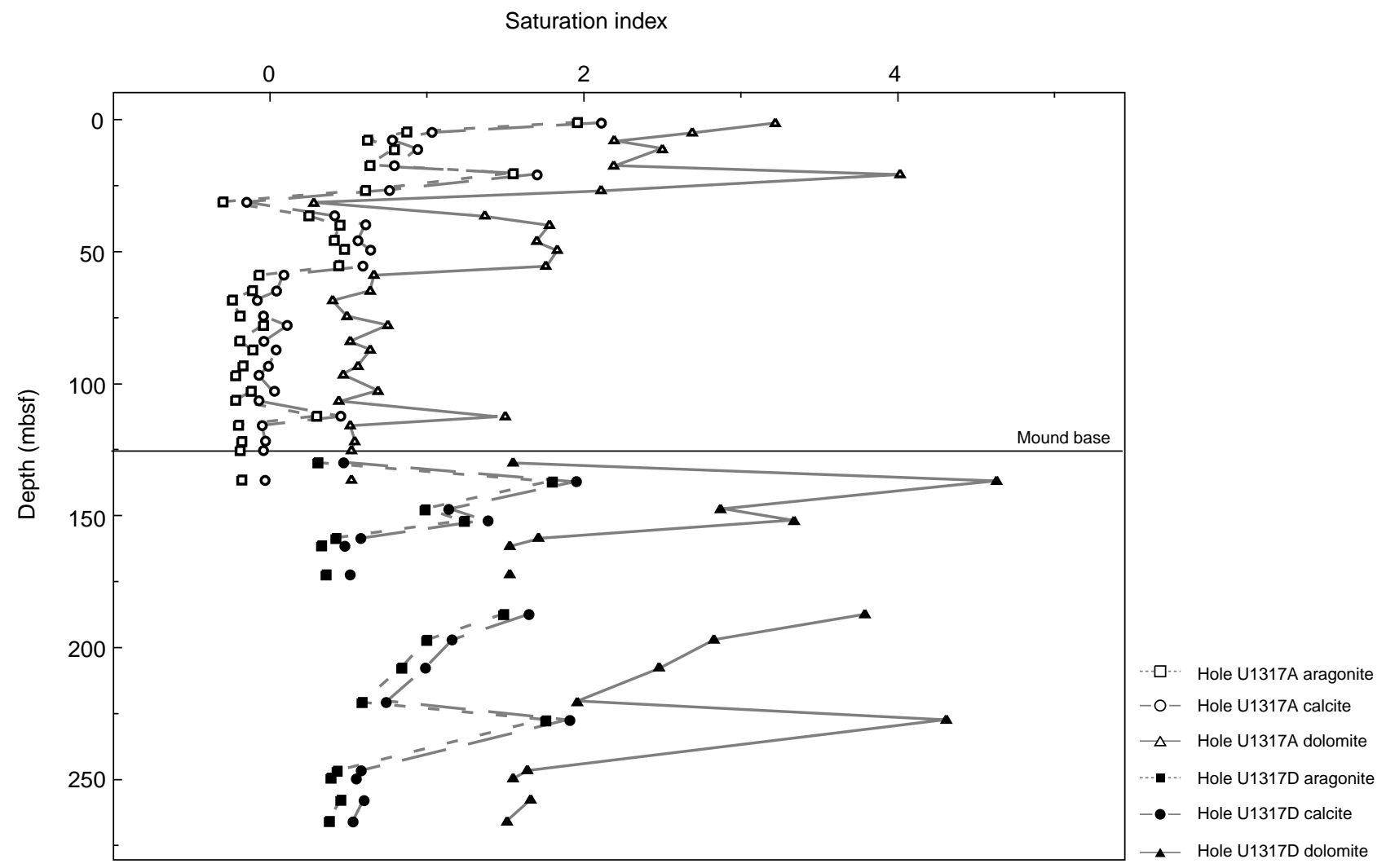

